\title{
Otimização da Técnica de Atomização Empregada Na Microencapsulação de Lactobacillus Acidophilus Empregando Proteínas do Leite e Maltodextrina Como Agentes Encapsulantes
}

Daiane Corti (I), Tania Becker-Algeri (II,I), Deisy Alessandra Drunkler (I)

(I) UTFPR - Universidade Tecnologica Federal do Paraná (Avenida Brasil, 4232 CEP 85884000 - Caixa Postal 271 - Medianeira - PR), (II) FURG - Universidade Federal do Rio Grande (Avenida Itália, km 8. CEP 96203900 Bairro Carreiros - Rio Grande - RS)

\section{Resumo}

Entende-se por probióticos microrganismos vivos, não patogênicos, que quando administrados em quantidade adequada periodicamente confere benefícios à saúde do consumidor. Um maior emprego destes microrganismos tem esbarrado na baixa estabilidade sob determinadas condições de processamento e/ou durante a passagem pelo trato digestório. A microencapsulação de probióticos tem sido empregada justamente para aumentar a estabilidade frente aos fatores acima mencionados. Assim, o trabalho avaliou a otimização das condições de microencapsulação do microrganismo Lactobacillus acidophilus La-5, que se destaca por ser um dos probióticos mais estudados e utilizados em nível industrial, utilizando a técnica de Spray Drying e solução de leite em pó desnatado concentrado acompanhada de maltodextrina como agentes encapsulantes, através do emprego de um planejamento experimental do tipo Delineamento Central Composto Rotacional (DCCR) com duas variáveis independentes, temperatura de entrada do ar $\left(64\right.$ à $\left.106^{\circ} \mathrm{C}\right)$ e concentração do agente encapsulante maltodextrina $(1,7$ à $23,7 \% \mathrm{~m} / \mathrm{v})$, tendo como variável dependente o Rendimento da Microencapsulação do microrganismo em estudo, totalizando 11 experimentos, com quatro pontos axiais e triplicata no ponto central. Os resultados indicaram que as faixas ótimas para maximizar o Rendimento da Microencapsulação do probiótico em estudo

\footnotetext{
Referência:

Daiane Corti, Tania Becker-Algeri, Deisy Alessandra Drunkler.Otimização da Técnica de Atomização Empregada Na Microencapsulação de Lactobacillus Acidophilus Empregando Proteínas do Leite e Maltodextrina Como Agentes Encapsulantes. In: Anais do $12^{\circ}$ Congresso Latinoamericano de Microbiologia e Higiene de Alimentos MICROAL 2014 [= Blucher Food Science Proceedings, num.1, vol.1]. São Paulo: Editora Blucher, 2014. DOI 10.5151/foodsci-microal-033
} 
abrangeram temperatura de entrada do ar de 100 a $106^{\circ} \mathrm{C}$ e concentração de maltodextrina entre 21 a $23,7 \%(\mathrm{~m} / \mathrm{v})$ e temperatura de entrada do ar de 64 a $70^{\circ} \mathrm{C}$ e concentração de maltodextrina entre de 1,7 a $2 \%(\mathrm{~m} / \mathrm{v})$; porém, nessa última faixa de estudo observou-se a formação de partículas mais higroscópicas, acarretando maior perda de material aderido às paredes do atomizador. Desta forma, foi possível microencapsular L. acidophilus La-5 empregando proteínas do leite e maltodextrina como agentes encapsulantes pela técnica de Spray Drying.

Palavras-Chave: Estabilidade, Microencapsulação, Probióticos Agência de Fomento: 